\title{
Developing The Mathematics Learning Strategy Book For Blind Students In Junior High School
}

\author{
Enggar Prasetyawan ${ }^{1)}$, Lisda Fitriana Masitoh ${ }^{2)}$ \\ ${ }_{1,2}$ Pamulang University, South Tangerang \\ *E-mail : englis.2202@gmail.com
}

\begin{abstract}
Blind students who do not have intellectual disabilities should study in inclusive schools. This is because they are the same as regular students who are able to learn and construct learning experiences well. They must get the best learning facilities to be successful. The purpose of this study was to produce a mathematics learning strategy book for blind students in junior high school. This book contains a general description of the characteristics of blind students, how to teach mathematics to blind students and class management strategies. This study is categorized as research and development. Development model in this study was adapted from Borg \& Gall. The research instruments were validation sheets, questionnaire assessment for teachers and questionnaire assessment for students. . Data analysis was done by converting the quantitative data into qualitative data in the form specified categories. This research resulted a mathematics learning strategy book for blind students in junior high school that proper to use because the book is valid and practical.
\end{abstract}

Keywords: Inclusion, mathematics, development, strategy, blind student.

\section{INTRODUCTION}

All citizens have the same rights to access an education, including blind students. This statement is in accordance with Law of the Republic of Indonesia Number 20 of 2003 concerning National Education System article 5 paragraph 1,"Every citizen has the same right to obtain quality education." This is the basis for providing comprehensive education for all people, including the blind. Blind people are classified into two groups, namely total blindness (blind) and low vision. Blind students who also have intellectual disabilities are called multiple disabilities.

Education in Indonesia facilitates blind students to study both in Special Schools (SLB) or inclusive schools. Inclusive schools provide opportunities for blind students to be able to pursue education the same as regular students in general. This is because blind students are the same as regular students in public schools who are able to learn and construct learning experiences well. They must get the best learning facilities to excel. However, the implementation of learning in inclusive schools with visually impaired students encounters many challenges and obstacles.

One of the challenges and difficulties for blind students is when they have to study mathematics (Pratama, Saputro \& Riyadi, 2018). Over the years, the constraints of blind people in learning mathematics have come to the attention of education practitioners (Giesen, Cavenaugh \& McDonal, 2012). Students must learn abstract concepts that regular students learn through visual media (Marson, Harrington \& Walls, 2012). This is what causes the average blind students have lower mathematical abilities compared to regular students. Whereas blind students must learn math skills at the same level as regular students (Tindell, 2006). In his 
research, Malasig \& Zhang (2015) revealed that there is a need to establish appropriate learning methods for blind students. It is important to be done because blind students need special methods for learning mathematics.

The implementation of inclusive education is the right step to provide maximum service to children with special needs including blind students (Triyanto \& Permatasari, 2016). Therefore, the existence of an inclusive school is now a hope for blind students to get a better learning experience. However, the implementation of inclusive school programs is certainly not as smooth as one might imagine. Various obstacles arise along with efforts to equalize education for blind students.

Based on research conducted by Susanto (2009), several conclusions are obtained about how blind students learn mathematics, especially when they complete algebraic operations related to the area and circumference of a rectangle. It turns out that blind students solve problems with a trial and error strategy and deliver results verbally. They do not use appropriate procedures so that it takes longer. This certainly makes it easy for students to forget about what they have learned. Based on this fact, Susanto (2009) suggests further studies to use alternative methods that utilize other senses to replace the function of the sense of sight so that blind students can learn optimally.

Another study was revealed by Rahmawati (2015) who conducted research on Jarimatika to help blind students in counting. It resulted in increasing of students' numeracy skills. This shows that every effort and creativity of the teacher in teaching mathematics, will be very influential for the success of blind students in learning mathematics. In line with the results of the above study, Tirta, Susanto \& Arika (2013) developed mathematical teaching aids with audio that includes the circumference and area of the triangle. The strength of the results of the development is that there is an additional display that is an interactive learning $\mathrm{CD}$ which becomes a special attraction for students. However, the material is only limited to building a flat triangle and certainly can only be accessed for special schools that can facilitate its use.

The obstacles in learning mathematics for blind students are also obtained from the results of research conducted by Nurmitasari (2015). The findings of the research conducted at one of the special high school which is the first way in class IX students in learning mathematics is just by listening. This is because schools do not yet provide a medium for learning mathematics for blind students. Secondly, teachers pay less attention to the characteristics of blind students and do not seek the use of tactile objects during the learning process. From these findings Nurmitasari (2015) suggests using visual aids to help blind students to learn mathematics.

The lack of teachers' ability to use specific strategies in teaching blind students is also evidenced by research conducted by Rahayu, Murni \& Efrina (2014). In their research, Rahayu, Murni \& Efrina (2014) suggested that the teacher did not understand the visual impairment experienced by students. In the implementation of learning, teachers did not use specific strategies for teaching. 
Material that was not possible to be taught to blind students, was not taught. Students learned only by relying on their sense of hearing. Putri (2012), in a study conducted at an elementary level inclusive school concluded that there was no accessibility for blind children in learning. One contributing factor was that teachers lack knowledge about how to teach blind children in regular schools. The facts revealed from various research results are certainly a concern for the world of education.

Based on some interviews with several teachers in inclusive schools in the Greater Jakarta area, it was obtained the fact that mathematics was considered as the most difficult subject for blind students to learn. The teacher had difficulty teaching mathematical concepts for blind students and students listened more so they could not follow the learning maximally. This fact indicates that there are still inclusive schools with blind students who have not been able to adapt to the demands of student learning. This condition is caused by two main factors, which are inadequate mathematics learning facilities (media / tools) and the lack of teacher's understanding of how to learn mathematics for blind students. Teachers in inclusive schools are well-versed in mathematics material but do not yet know the learning strategies for blind students.

Based on the results of previous studies and facts that occur in the field, researchers intend to conduct research to develop a strategy book to teach mathematics for blind students in junior high school. This book will contain a description of the general characteristics of blind students, how to teach mathematics to blind students and inclusive class management strategies. In addition, there will be examples of the use of simple media from materials around students in learning mathematics.

\section{RESEARCH METHOD}

This research is included in the type of research and development. The development in this research is the development of a strategy book on learning mathematics for blind students. The researcher used the development model by the Borg \& Gall (1983) which is modified and adapted to the research needs. The quality of development products must be tested to determine the quality of development products in terms of validity, practicality and effectiveness (Nieveen: 1999), however in this study, researchers have not yet reached the effectiveness test stage. In general, there are 6 steps that are used in research and development:

1. Research and Data Collection

In this stage, an initial survey is conducted to determine the urgency of the research. In addition, a theoretical study and previous studies were carried out to strengthen the research plan.

2. Planning

The researcher Plan research development steps to ensure the implementation of research.

3. Develop Preliminary Form of Product 
In this stage various research instruments were developed. The draft development product that will be used in a limited trial must pass validation from an expert.

4. Preliminary Field Testing

The researcheer conducted limited trials to determine the quality of the product in terms of practicality.

5. Main Product Revision

Product revisions are based on the results of limited trials or readability trials.

6. Dissemination

The final product of development was disseminated to be used to improve the quality of mathematics learning in schools. In addition, the results of development research are also disseminated through publications in reputable journals.

The subjects of the product development trial were two inclusive school students in the Greater Jakarta area. Data collection instruments used were instruments to determine validity and practicality. The type of data obtained from this research and development are quantitative and qualitative data. Quantitative data were obtained from scores given by the validator in the validation stage, assessment scores from practitioners (teachers) and students. Qualitative data were obtained from validator input and also from the conversion of quantitative data to specified categories.

In this study, researchers used a questionnaire to obtain data. Data collection instruments consist of instruments to determine validity and practicality. The instrument for knowing validity consisted of book validation sheets, while instruments to determine practicality consist of teacher assessment sheets and student assessment sheets. Data analysis was carried out to get a picture of the quality of the product that was developed from the aspects of validity and practicality. Quantitative data is converted into qualitative data on a four scale for the validation data analysis, teacher assessment data and student assessment data. The references used to change the score to a scale of four are presented in Table 1 below.

Tabel 1. Converted Actual Score into four Scale Score

\begin{tabular}{cc}
\hline Range of Score & Category \\
\hline$X \geq \overline{\mathrm{x}}+1 . \mathrm{SB}_{\mathrm{x}}$ & Excellent \\
$\overline{\mathrm{x}}+1 . \mathrm{SB}_{\mathrm{x}}>X \geq \overline{\mathrm{x}}$ & Good \\
$\overline{\mathrm{x}}>X \geq \overline{\mathrm{x}}-1 . \mathrm{SB}_{\mathrm{x}}$ & Poor \\
$X<\overline{\mathrm{x}}-1 . \mathrm{SB}_{\mathrm{x}}$ & Bad \\
\hline
\end{tabular}

(Adapted from Mardapi, 2004)

Notes:

$\mathrm{X}$ : respondent score

$\overline{\mathrm{X}} \quad$ : ideal mean 
$\mathrm{SB}_{\mathrm{x}} \quad$ : ideal standard deviation

where:

$\overline{\mathrm{X}}=\frac{1}{2} \mathrm{x}$ (ideal max score + ideal min score $)$

$\mathrm{SB}_{\mathrm{x}}=\left(\frac{1}{6}\right) \mathrm{x}$ (ideal max score - ideal min score $)$

Product development is considered as valid if the results of the assessment of experts obtain a minimum category of good. Product development is considered as practical if the teacher assessment results get a good minimum category and student assessment results get a good minimum category.

\section{RESULT AND DISCUSSION}

The product developed in this research is a strategy book on learning mathematics for blind students in junior high school. This book consists of several sections, including the characteristics of blind people, mathematics learning for blind students and inclusive class management. In this book, examples are given of using media or simple tools that are easy for teachers to make. The book development process is carried out by conducting a literature review on the characteristics of blind students and interviews. The findings are narrated in the book to provide a brief description of the characteristics of blind students. In addition, a literature review was conducted to provide recommendations for mathematics classroom management in which there are blind students. This book also provides recommendations for tools or media that teachers can make to help blind students learn mathematics.

The quality of development products in terms of validity is known through the results of validation. Validation is carried out by a mathematics lecturer and an education practitioner who is experienced in teaching blind people. The validation results show that the product developed meets the valid criteria with an average score of 45.5 and the category is very good. Product development is valid because it was developed with relevant theoretical support. In addition, the tools recommended in the book are not necessarily used as recommendations. The development team conducted a variety of experimental equipment and it was tested to find out if the media is accessible for blind students. One simple media that can be used in learning mathematics is paper. Paper that is folded or better known as paper folding can be used to teach many mathematical concepts, including flat shapes, cartesian coordinates, lines and others.

For blind students, learning experience must be obtained by using the senses that are still functioning, especially touch and hearing. However, the use of these senses cannot produce output directly and quickly as in students who are able to see, for example to understand the size and dimensions of three. Blind students will rely heavily on memory and touch. When students explore an object with a palpable process, it means they are trying to explore parts to the whole. The challenge is when students have to learn objects that are impossible for them to touch, such as buildings, dangerous animals, etc., these objects must be modeled by the teacher.

Brawand \& Johnson (2016), in their research concluded that blind students will find it easier to learn mathematics by using a combination of abacus, 
braille codes, tactile materials and concrete materials. In Indonesia, mathematical learning aids for blind students have been bought and sold, but the price is quite expensive. This makes it difficult for teachers or schools in general to access these tools. Especially if the school is in a remote area. Basically, teachers are required to be creative and innovative when teaching blind students. When media or tools that are supposed to be used as models do not exist, there must be an alternative. The tool can be made simply from materials that are easily found by the teacher, including waste or used goods. Therefore, there should be no reason blind students do not learn a mathematical concept because there is no visual aid and can only be drawn or symbolized.

In addition to the use of media, teachers need to think about class management with blind students. The teacher must understand the characteristics of the visually impaired, especially those related to cognitive and academic. One important class management strategy is to make the classical approach that can also be followed by blind students. In learning practices, teachers often take a classical approach to make lessons more effective and efficient. For example, when studying building material, the teacher shows the model of building space in front of the class, asking students to pay attention to what is demonstrated and give students the opportunity to investigate their properties. This activity will not be able to be followed by blind students, because they cannot see what the teacher is demonstrating. In this case, the teacher can ask blind students to be a model that holds a model of building space in front of the class. This method can make regular students and blind students not lose the opportunity to understand the material.

The visual approach must be eliminated in the inclusion class with blind students. This is a challenge for teachers as teachers usually write a lot or illustrate mathematical objects on the board. In regular classes, even teachers often say the words "this" and "that" to simplify the explanation on the board. This certainly will make blind students confused. In an inclusive class with blind students the teacher must narrate what is on the blackboard. In learning mathematics, narrating mathematical mathematics is not as easy as narrating a story. Wrong narration, will lead to biased meaning. For example, a teacher narrates a math problem:

$$
y=\frac{2 x+3}{4}
$$

If the teacher narrates with the sentence "y is equal to $2 x$ plus 3 per $4 "$ then it will cause a biased meaning. It would be more appropriate for the teacher to narrate it, as " $y$ equals the quotient of $2 \mathrm{x}$ plus 3 by 4 ". This narrative will be unfamiliar to students who are not used to it. However, if the teacher starts to get used to narrating the problem with the right mathematical language, students will become accustomed.

Furthermore, in order to provide evaluations in the form of tests to blind students, the teacher can use several methods including: (1) Equate the number of questions with regular students, but with different time allocations. Blind students in general will need more time working on the questions. Not because of cognitive 
abilities, but rather the writing process, both in braille writing or using a computer. (2) Reducing the number of questions by not reducing the competency that must be mastered by target students. Sometimes the teacher gives more than one problem to measure the achievement of one learning indicator. For blind students, the teacher can reduce the number of questions, by choosing questions that are able to measure the achievement of learning indicators. Thus the allocation of time to work on the questions could be the same between blind students with regular students. (3) Perform oral and practical tests. There are some competencies that are not possible for blind students to take written tests. If this competency is measured, the teacher can take an oral or practice test, such as in the Cartesian coordinate material. In this material, students are asked to show the Cartesian coordinates where point A $(2,-4)$ is located. Then students can show it on geoboard or other media prepared by the teacher.

The practicality of the product development is known based on the results of the practitioners' evaluation in this case the teacher conducting product trials and student assessments in trial activities. Based on the results of the teacher assessment questionnaire obtained an average score of 26 with a good category. The results show that the book developed meets practical criteria in terms of teacher assessment. Based on the results of the student assessment questionnaire, an average score of 25.5 was obtained with either category. These results indicate that the book developed meets practical criteria in terms of student assessment. The effectiveness of development products in the form of this book, can actually be known from the results of student achievement tests. However, this development process has not yet reached the stage of quality testing within the effectiveness criteria. Product quality development in terms of effectiveness will be carried out in further research.

\section{CONCLUSION AND SUGGESTION}

\section{Conclusion}

Based on the results of the study and discussion, the following conclusions are obtained. First, the strategy book on learning mathematics for blind students in junior high school was developed through scientific stages, namely: (1) research and data collection, (2) planning, (3) initial product development, (4) limited trials, (5) product revisions and (6) dissemination. Secondly, this development product is feasible to use because the strategy book teaches the blind students in junior high schools to meet valid criteria with excellent categories based on the results of expert validation and meet practical criteria with good categories based on teacher and student assessment results.

Suggestion

Suggestions from the development of a strategy book to teach mathematics to junior high school students is teachers are expected to use books developed to assist in the management of inclusive classrooms with blind students, especially in learning mathematics. Secondly, this book can be used as a reference in research or studies relating to mathematics learning for blind students. Thirdly, further research needs to be conducted to determine the quality 
of product development in terms of effectiveness through the real learning process in the classroom.

\section{REFERENCES}

Borg, W. R., \& Gall, M. D. (1983). Educational research an introduction. New York, NY: Longman.

Brawand, A., \& Johnson, N. (2016). Effective Methods for Delivering Mathematics Instruction to Students with Visual Impairments. Journal of Blindness Innovation anda Research, 6 (1).

Departemen Pendidikan Nasional. (2003). Undang-Undang Nomor 20 Tahun 2003, Tentang Sistem Pendidikan Nasional, Jakarta: Depdiknas.

Giesen, J. M., Cavenaugh, B. S., \& McDonal, M. C. (2012). Academic Supports, Cognitive Disability And Mathematics Acheivement For Visually Imparied Youth: A Multilevel Modeling Approach. International Journal Of Special Eduation, 27 (1), 17-26.

Malasig, J.A., \& Zhang, D. (2015). Ali, M. (2010). A Review of Literature: Mathematics Instruction for. Journal of Childhood \& Developmental Disorders, 2 (1). 1-4.

Mardapi, D. (2004). Penyusunan Tes Hasil Belajar. Yogyakarta: UNY.

Marson,S. M.,Harrington, C.F.,\& Walls, A. (2012). Teaching introductory statistics to blind students. Teaching Statistics, 35 (1), 21-25.

Nieveen, N. (1999). Prototyping to reach product quality. Dalam J.V. den Aker, et al. Design approaches and tools in education and training. (pp. 125-136). London: ICO Cluwer Academic Publisher.

Nurmitasari. (2015). Pola Penerimaan Siswa Tunanetra Dalam Pembelajaran Matematika Di SMPLB. Jurnal e-DuMath, 1 (2), 82-88.

Pratam., Saputro., \& Riyadi. (2018). Problem solving of student with visual impairment related to mathematical literacy problem. Journal of Physics: Conf. Series 1008, 012068.

Putri, D. Y. F. (2012). Proses Pembelajaran Pada Sekolah Dasar Inklusi. Jurnal Ilmiah Pendidikan Khusus, 1 (3), 168-179.

Rahayu, R., Murni, I., \& Efrina, E. (2014). Penyelenggaraan Pendidikan Inklusif Bagi Anak Tunanetra Low Vision. Jurnal Ilmiah Pendidikan Khusus, 3 (3), 1-15.

Rahmawati, S. (2015). Peningkatan Kemampuan Berhitung Melalui Metode Jarimatika pada Siswa Tunanetra. Jurnal JRR, 24 (1), 1-11.

Susanto. (2009). Proses Berpikir Anak Tunanetra Dalam Menyelesaikan Operasi Aljabar Pada Permasalahan Luas Dan Keliling Persegi Panjang. Seminar Nasional Aljabar, Pengajaran Dan Terapannya. Yogyakarta: FMIPA UNY, 31 Januari 2009.

Tindell, M. (2006). Technology and life skills: A beginner's guide to access technology for blind students. Future Reflections, 25(2). 
Tirta., Susanto., \& Arika. (2013). Pengembangan Alat Peraga Matematika Berbasis Audio Pada Pokok Bahasan Keliling Dan Luas Segitiga Untuk Siswa Tunanetra Smplb Tpa Jember. Kadikma, 4 (1), 103-114.

Triyanto., \& Permatasari, D.R. (2016). Pemenuhan Hak Anak Berkebutuhan Khusus Di Sekolah Inklusi. Jurnal Sekolah Dasar, 25 (2),176-186. 